\title{
RETIREMENT AND SOCIAL SECURITY: A TIME SERIES APPROACH
}

\author{
Brendan Cushing-Daniels and C. Eugene Steuerle*
}

CRR WP 2009-1

Released: January 2009

Draft Submitted: December 2008

\author{
Center for Retirement Research at Boston College \\ Hovey House \\ 140 Commonwealth Avenue \\ Chestnut Hill, MA 02467
}

Tel: 617-552-1762 Fax: 617-552-0191

* Brendan Cushing-Daniels is a professor of economics at Gettysburg College and a consultant at the Urban Institute. C. Eugene Steuerle, formerly a Senior Fellow at the Urban Institute, is Vice President of the Peter G. Peterson Foundation. The research reported herein was performed pursuant to a grant from the U.S. Social Security Administration (SSA) funded as part of the Retirement Research Consortium (RRC). The findings and conclusions expressed are solely those of the authors and do not represent the views of SSA, any agency of the Federal Government, the RRC, the Peterson Foundation, Urban Institute, its trustees, or its funders.

(C) 2008, by Brendan Cushing-Daniels and C. Eugene Steuerle. All rights reserved. Short sections of text, not to exceed two paragraphs, may be quoted without explicit permission provided that full credit, including (C) notice, is given to the source. 


\title{
About the Center for Retirement Research
}

The Center for Retirement Research at Boston College, part of a consortium that includes parallel centers at the University of Michigan and the National Bureau of Economic Research, was established in 1998 through a grant from the Social Security

Administration. The Center's mission is to produce first-class research and forge a strong link between the academic community and decision makers in the public and private sectors around an issue of critical importance to the nation's future. To achieve this mission, the Center sponsors a wide variety of research projects, transmits new findings to a broad audience, trains new scholars, and broadens access to valuable data sources.

\author{
Center for Retirement Research at Boston College \\ Hovey House \\ 140 Commonwealth Avenue \\ Chestnut Hill, MA 02467 \\ phone: 617-552-1762 fax: 617-552-0191 \\ e-mail: crr@bc.edu \\ www.bc.edu/crr
}

\author{
Affiliated Institutions: \\ The Brookings Institution \\ Massachusetts Institute of Technology \\ Syracuse University \\ Urban Institute
}




\begin{abstract}
Traditional analyses of retirement decisions focus on the age, from birth, of the individual making choices about how much to work, consume, and save for old age. However, remaining life expectancy is arguably a better way of examining these issues. As mortality rates decline, people at a given age now have more remaining years of life expectancy than they did in the past. If participation rates at older ages remain constant (or decline), then average time spent in retirement will increase. Additionally, because health status and mortality are correlated, adults with more expected years of life are generally in better health (and better able to work) than those with fewer years of remaining life.
\end{abstract}

This paper examines labor force participation rates of older workers considering both chronological age and remaining life expectancy. Results show that participation by remaining life expectancy declines for men through the early 1990s, leveling off in the next decade. However, participation by age have been rising for men in their sixties since the mid-1990s. Whether we specify the empirical model by age or by remaining life expectancy, ages 62 and 65 both have strong negative effects on participation, confirming a major role in retirement decisions for Social Security. Finally, we find that controlling for other factors - education, marital status, and business cycle effects magnifies the decline in participation attributable to cohort effects for men born between 1900 and 1960, but reduces the importance of cohort effects for women born in these years. 


\section{Introduction}

Labor supply decisions, including decisions to participate in the labor force, vary over the life cycle. Participation rates rise in the teens and twenties, plateau in the late twenties and early thirties, and begin to decline in the early fifties. These patterns now hold for both men and women. The labor force participation-by-age curves for men and women are more similar today than even 20 years ago, with participation rates lower for men than they have been in the past and higher for women. Nevertheless, while rates for men still peak around 90 percent, the peak for women is closer to 80 percent (Szafran 2002).

Both male and female participation rates decline after age 55, as workers begin to retire. The retirement transition has important consequences not only for workers and their families, but also for society as a whole. As baby boomers reach the eligibility age for retirement benefits under Social Security and the number of workers per retiree begins to plunge, an already underfunded system increasingly needs substantial reform. The brain drain that will result as older workers retire will likely reduce productivity. Consequently, retaining older workers in the labor force has recently become a high priority public policy issue (c.f. Eyster et al. 2008; Johnson et al. 2007; Toder et al. 2008).

While labor force participation rates decline at older ages, rates for older adults have been increasing in recent years. Participation rates remain lower than at earlier ages, but there is a definite trend up, reversing at least 30 years of declining participation rates among older Americans. For example, in Figure 1, participation at age 66 has 
declined for men between the pre-1896 birth cohort and the 1916-1925 birth cohort (point A to point B), but participation at age 66 is much higher for the 1936-1945 birth cohort. The trend is more consistently higher for later birth cohorts among women (Figure 2).

Remaining life expectancy (RLE) is arguably a better way of looking at these data. As mortality rates decline, people at a given age now have more remaining years of life expectancy than they did in the past. If participation rates at older ages hold constant (or decline), then average time spent in retirement will increase. Additionally, because health status and mortality are correlated, adults with more expected years of life are generally in better health (and better able to work) than those with fewer years of remaining life. Examining how labor force participation has changed over time with respect to RLE, then, may be more informative than looking at changes with respect to age.

This paper examines the labor force participation rates of those aged 55 and older. In particular, we examine these decisions looking both at chronological age and at remaining life expectancy. First, we examine the raw data - that is, what is happening to labor force participation of men and women at specific ages $(60,62$, and 65$)$ and at the equivalent number of years of remaining life in 2005. There is a dramatic decline in labor force participation for men at each of these ages in the last half century while women are participating more. In the last decade, however, older workers are working more. Second, we examine the participation decision using a logit model. Under a variety of specifications, we find that the ages of 62 and 65, more strongly for men but also for women, act as triggers for retirement. 
The rest of the paper is organized as follows. In Section II, we review the literature on the determinants of retirement behavior. In Section III, we discuss the data and methodology, and we examine the raw participation results. Section IV presents our descriptive results and Section V, our logit results. We conclude in Section VI.

\section{Literature Review for Determinants of Retirement in the United States}

This review of the determinants of retirement is not intended to be exhaustive, but to provide context in which to view this paper. An early review of the economic determinants of retirement is found in Quinn et al. (1990). The main factors we analyze are Social Security, private pensions, and health and health insurance.

Few topics have been as thoroughly studied as the influence of Social Security on retirement. Here we focus on three aspects of Social Security: Social Security wealth (SSW), the early and normal retirement age, and the elimination of the earnings test under Social Security for those who have reached the normal retirement age. One of the ways that forward-looking models of the impact of future Social Security benefits on retirement have evolved is along the lines of option value models of retirement. These models assume individuals choose their retirement date to maximize lifetime utility, which is a function of pre- and post-retirement income. Samwick (1998) finds that in a model that ignores pension wealth, Social Security wealth has no statistically significant effect on retirement, but this result may arise from his method of imputing Social Security wealth in the Survey of Consumer Finances (SCF). In his simulation, a 20 percent reduction in benefits reduces the probability that a 70-year-old is retired by only 1 percent. 
Using the Health and Retirement Study (HRS), Coile and Gruber (2000) find a much stronger effect of Social Security on retirement, partly because HRS respondents are linked to Social Security earnings records, providing the authors with a better measure of Social Security wealth. First, they are able to estimate effects separately for SSW and pension wealth, and they are able to isolate the effects of wages (both the direct effect and the indirect effect through SSW) in the option value model much more precisely. They construct a 'peak value' of Social Security wealth, "the difference between SSW at its maximum expected value and SSW at today's value” (emphasis in original). Controlling for pension wealth as well as SSW, the authors find that an additional $\$ 1,000$ in peak value reduces retirement probabilities by 0.025 percent, about 0.5 percent of baseline retirement rates.

Though not strictly following the methodology of the option value literature, Coile and Levine (2007) merits some attention here. The authors assess whether Social Security (or Unemployment Insurance) matters in the retirement decision during recessions. Interestingly, they find that a 3 percent increase in the unemployment rate (their gauge of the rise associated with movement from peak to trough in a business cycle) significantly increases the likelihood of retirement but only for those who are already eligible for Social Security. They conclude that the interactions of Social Security and labor market conditions are important determinants of the retirement decision.

In addition to the general effect of Social Security wealth on retirement, program variables, like the age of eligibility, also play an important role in the retirement decision. Since 1961, workers first become eligible for retirement benefits at age 62, but they 
receive a lower monthly benefit than they would at the full retirement age (FRA), the age at which workers become eligible for the full retirement benefit. For two-thirds of a century, the FRA was 65 but the Social Security Amendments of 1983 raised the FRA to 67 and increased the penalty for workers retiring at age 62. As might be expected, much of the early literature finds significant spikes in the retirement hazard—-the number of people retiring at a given age as a fraction of those eligible to retire—at ages 62 and 65. Burtless and Moffitt (1984) find no spike at age 62 prior to 1961, and they find a consistent pattern of retirement at age 65 both before and after the legislative change. Ruhm (1995) finds that the hazard rate at age 62 is over three times as large as the average for ages 58-61 in 1989, and Hurd (1990) notes that "the peak in the hazard at 62 is good evidence that Social Security has some effect on retirement.” By 1986, half of all men are retired by age 62 (Hurd 1990). Coile and Gruber (2007) also find large spikes in retirement at ages 62 and 65 between 1980 and 1999. Using forward-looking models of earnings and wealth accrual, the marginal effects at age 62 are five times as large as the effects for ages 60 and 61, and the effects at age 65 are nearly 3 times as large as those at age 64 .

There is a long literature on the effects of the Social Security earnings test on hours of work, but we do not review that here. Instead, we review the much briefer and more recent literature on the effects of the earnings test on retirement. In the first evaluation after the elimination of the earnings test for 65- to 69-year-olds, Song (2003) finds a 2 percent increase in the pace of application for Social Security benefits among 65- to 69-year-olds. The effect is seemingly small, but it should be noted that the vast majority of insured workers have already applied for benefits by age 65. Gruber and 
Orszag (2000) "find evidence that loosening the earnings test leads to increased benefits recipiency, ... and that complete removal would increase [the share of the elderly receiving benefits] by 5.2 to 13.5 percent.” Finally, Friedberg and Webb (2006) find that eliminating the earnings test in 2000 increases the probability of working at all during the year for 65- to 69-year-olds. Using Current Population Survey data, the probability rises by 1.3 percent for 65 -year-olds and by about 0.5 percent for 66 - to 68 -year-olds, but using the Health and Retirement Survey these probabilities rise by 3.5 percent for 65year-olds and by 2 percent for 66- to 69-year-olds. In short, the elimination of the earnings test raises both benefit receipt and employment.

\section{Private Pensions}

Private pensions also play an important role in a worker's decision to retire. Both access to a private pension and the type of private pension to which one has access affect retirement probabilities. Utilizing data from the Retirement Confidence Survey of College and University Faculty from TIAA-CREF, Manchester (2007) finds that workers with a defined contribution (DC) pension plan expect to retire eight months later than their counterparts with a defined benefit (DB) pension plan. Those workers who choose a DB plan expect to retire another half year earlier than those who are only offered a DB plan. The word 'choose' is highlighted because only some workers are really faced with a choice between a DB and a DC pension; most are given only one or the other. Interestingly, those workers who are not covered by Social Security are significantly more likely to choose a DB pension plan over a DC plan compared to those who are covered by Social Security. This suggests that workers are choosing to diversify their 
risk in retirement by choosing a DC plan more frequently if they already have the DB coverage provided by Social Security.

Friedberg and Webb (2005) attribute the recent increase in retirement ages (noted, for example, in Gendell (2001)) to the movement away from DB pensions toward DC pensions. They note that "[r]etirement patterns begin to diverge at around age 55 and accelerate around age 60 when most workers with DB plans begin to experience negative accruals.” The fact that workers with DB pension plans, on average, retire two years sooner than their counterparts with DC pensions leads the authors to conclude that it is the variable (and sometimes negative) accrual rates by age in DB pensions that lead to earlier retirement among those workers with a DB plan.

Using data from the HRS, Chan and Stevens (2004) analyze the effects on subjective retirement probabilities of increased pension wealth from delaying retirement. Methodologically, the estimation is similar to that of many of the papers above on the effects of Social Security on retirement. However, the authors look specifically at the effects of private pension accumulations controlling for individual fixed effects. Their findings suggest that average pension gains lower the probability of retiring at age 62 between 2 and 7 percent. While these effects are substantial, they appear to be much smaller than the marginal effect of increases in Social Security wealth found in Coile and Gruber (2007). Blundell et al. (2002) find qualitatively similar results for the UK.

\section{Health and Health Insurance}

It is possible that the effects of pension coverage on retirement are overstated in those studies that do not control for access to health insurance. Rogowski and Karoly (2000) make exactly this point using the HRS to study the effects of health insurance on 
retirement decisions. These authors find that workers with retiree health benefit offers are 68 percent more likely to retire than those who would lose insurance coverage upon separation from employment. Those with non-employment linked health insurance in retirement are also more likely to retire than those facing the loss of health care coverage. These results largely extend and confirm the results from Rogowski and Karoly (1994) which used data from the SIPP. Blau and Gilleskie (2003) find only modest effects of access to employer-provided retiree health insurance (EPRHI) on retirement decisions of older men; men who gain EPRHI increase retirement (non-employment) by about 1 percent, and those who lose EPRHI reduce retirement by 1 percent. These are significantly smaller than the effects found in Blau and Gilleskie (2001) who note that their results were larger than previous estimates in the literature, probably due to controls for heterogeneity. The key difference between the earlier and later Blau and Gilleskie papers is the use of a reduced form model in the earlier paper. This may also explain the lower estimates in the latter paper.

In addition to coverage itself, the cost of health insurance coverage also reduces the likelihood of retirement. Even those workers who have retiree health insurance (RHI) often pay significant premiums to maintain the coverage. Johnson et al. (2003) report that the mean cost to retirees with this benefit is roughly triple the cost to those workers when they were working. They find that "[i]f men with employer-sponsored coverage but without RHI offers faced the same mean monthly premium cost to retire as do those with RHI offers, their predicted retirement rates would increase by $26 \%$,” and the corresponding figure they report for women is 31 percent. 
Medicare as a Second Payer (MSP) legislation requires that employer-sponsored health insurer be a worker's primary insurance payer (if the beneficiary is employed). Despite good intentions to reduce the cost of Medicare, the system has generated implicit taxes on work at older ages that are 15 to 20 percent at age 65 and rise to 45 to 70 percent at age 80 (Goda et al., 2007). These taxes are rising over time, as well, for both men and women above the age of 64 .

While health insurance matters for the elderly in general, it stands to reason that it would matter more to those who are or expect to be in poorer health. Health status itself, then, is also a determinant of retirement behavior. Dwyer and Mitchell (1999) use the HRS to study the effect of self-reported health on retirement, correcting for the endogeneity of self-reported health status. A number of earlier studies (e.g. Anderson and Burkhauser 1985) confirm the endogeneity problem, but even correcting for this endogeneity, Dwyer and Mitchell find that those with poor self-reported health expect to retire between one and two years earlier than their healthier counterparts. ${ }^{1}$ Bound et al. (2007) estimate a latent variable model to overcome concerns about the endogeneity of self-reported health status. Also using the HRS, the authors estimate that a typical man in poor health is 10 times as likely to retire before eligibility for any pension benefits as a similar person in average health.

A recently published study (Schirle 2008) attributes the rise in labor force participation among older men to the rise in participation among their wives, noting that leisure among husbands and wives are complements. While this may explain part of the trend, it is insufficient to explain the full story. For example, Figures 11 and 12 below

\footnotetext{
${ }^{1}$ Bound (1991) notes that using the 'objective' measures of health status can be as problematic as using the self-reported measures and that using one to instrument the other presents other challenges in each case.
} 
show the labor force participation rates for never married, married, and 'other' men aged 55 to 75 since $1990 .^{2}$ While it is true that the series for never married men is 'noisier,' the trends for 55- to 59-year-olds and for 70- to 75-year-olds are not distinguishable across marital status.

Finally, it is important to note that a new literature is emerging that examines retirement decisions and labor force participation of older workers in the context of remaining life expectancy rather than chronological age. Shoven (2007) looks both at RLE and at mortality risk as different ways of measuring 'age.' He finds that the 'wave' of elderly coming through the population is dramatically smaller when viewed from the perspective of mortality risk, and when viewed from the perspective of RLE rather than traditional age, stabilizing participation rates at today's levels will lead to a 10 percent increase in labor supply by 2050. Thus, if workers are making their decisions to retire based on consideration of how much longer they expect to live rather than on having achieved a certain age, we might get dramatically different results than traditional models assume.

\section{Data and Methodology}

We examine labor force participation at older ages in this paper. Our interest is in whether there are significant differences in the decisions of older workers when we examine them by age and by RLE. To do this, we examine simple trends over time by age/RLE, sex, and cohort. The data on labor force participation rates (LFPRs) for older men and women for this study come from the March Supplement to the Current Population Survey (CPS) from the US Census Bureau. The data for 1940, 1950 and 1960

\footnotetext{
2 “Other” men include divorced, separated, and widowed men.
} 
come from decennial censuses, and the data from 1965 to 2007 come from the CPS. Data for our empirical (logit) models also come from the CPS. Data on remaining life expectancy are taken from the 2008 report of the Trustees of the Social Security system.

We present labor force participation rates by age and by equivalent RLE for men (Figures 5-7) and women (Figures 8-10). The RLE equivalent is chosen to coincide with the age of interest in 2005. So, for example, men age 62 in 2005 have 19.5 years of remaining life expectancy. Thus, we present the LFPRs for men with 19.5 years RLE in the graph with men age 62. As life expectancy has increased over the last 70 years, men with 19.5 years RLE were only 55 in $1950 .^{3}$

Our empirical model is a logit specification for labor force participation for older workers, where participation is modeled as a function of age/RLE, age 62 and age 65 dummies, SSDI beneficiaries as a fraction of 25- to 64-year-olds, the population share of 20- to 29-year-olds, marital status, education, and birth cohort fixed effects. The data come from 1976-2007 CPS, and the models are estimated separately by sex. Education is captured in dummy variables for high school graduates, those with some college, and college graduates; the omitted category includes those with less than a high school education. The omitted category for marital status includes divorced, separated, and widowed persons, and the included dummy variables are married and never married. Formally, the logit model is

$\log i t\left(p_{i}=\ln \left(\frac{p_{i}}{1-p_{i}}\right)=\beta_{0}+\beta_{1} x_{1, i}+\ldots+\beta_{k 1} x_{k, i}\right.$

where

\footnotetext{
${ }^{3}$ The graph for 62-year-old men only goes back to 1950 because we limit ourselves in this analysis to those men and women aged 55 and older. Men with 19.5 years RLE prior to 1950 were younger than 55 years old.
} 


$$
p_{i}=\frac{1}{1+e^{-\left(\beta_{0}+\beta_{1} x_{1, i}+\ldots+\beta_{k 1} x_{k, i}\right)}}
$$

\section{Descriptive Results}

We now turn to our discussion of the raw participation rates shown in figures 5 to 10. We generate these rates by RLE by matching Social Security data on remaining life expectancy to our sample members. ${ }^{4}$ The first thing to note about the three graphs for successively older workers is that labor force participation declines from the 1960s through the early 1990s, but that trend is reversed in the most recent decade for ages 60, 62, and 65. However, participation at the equivalent RLEs for those ages does not increase but merely levels off since 1995. The fact that participation is leveling off by remaining life expectancy may suggest either that workers have been preparing for a certain number of years in retirement or that work is less debilitating now (in a service economy) than it had been in the past (in a more heavily manufacturing economy) and thus is the source of less disutility than in the past.

In Figure 5, then, what explains the declining labor force participation rate for 60year-old men from 1965 to 1995? First, widespread use of DB pensions at the time provided significant incentive to retire, even prior to eligibility for Social Security benefits. Second, qualifying for disability benefits under Social Security has become easier over time. In 1965, just under three-quarters of a million workers were on SSDI, but by 1995, that number had risen to over 2.5 million workers. Not all of these workers had attained age 60, but the difference is quite striking nonetheless. Duggan et al. (2007)

\footnotetext{
${ }^{4}$ A detailed description of the procedure is available from the authors upon request.
} 
present compelling evidence of the increase in DI beneficiary status, particularly for women, at older ages over the past quarter century.

In Figures 6 and 7, we see first divergence, then convergence in the LFPR by age/RLE graphs. The convergence is, in a sense, mechanical. Given the way we choose the age/RLE pairs, in 2005, the labor force participation (LFP) rates must be equal in 2005. Thus, the LFP curves are forced to converge. On the other hand, there is no such compelling reason for these rates to diverge. In Figure 6, for example, the difference in participation rates for 62-year-olds and for those with 19.5 years RLE in 1965 is about 10 percent. By the early to mid-1980s, however, the difference is nearly twice as high. Similarly in Figure 7, the gap in participation between 65-year-olds and those with 17 years RLE widens after 1965 but then narrows, slowly at first, but much more rapidly after 1980 .

The fact that participation declines for each of the RLEs we examine suggests that it is not only remaining life expectancy that workers consider in deciding to retire or not. If it were, then we should see nearly constant participation rates by RLE. Declines by age in participation rates between 1965 and 1990 are much steeper than those by RLE, but then they flatten out dramatically. In fact, after 1990 and for most ages above 54, participation is rising slightly over time. This is not the result of particular workers working more that they did the year before, but of younger cohorts working more as they age than their predecessors did (see Figure 3).

The story for women is more straightforward in the graphs (Figures 8-10). In each case, the trend both by age and by RLE is strongly positive from the 1940s to about 
1965, flattens for the next twenty years, and then rises after the mid 1980s. There is virtually no divergence in the patterns by age versus RLE.

\section{Logit Results}

Results for men and women by age are presented in Tables 1-2, and results for men and women by RLE are presented in Tables 3-4. For ease of comparison, we present results for the base model (model 1) first, presenting the models that include a fuller set of explanatory variables to the right of Model 1 . Model 6 contains the full set of control variables. In the base model by age, we regress labor force participation on cohort effects and age/RLE. ${ }^{5}$ These results closely reflect Figures 1-4. Specifically, for men, controlling for either age or RLE, earlier cohorts work more, and later cohorts work less. For women, using the same controls, the opposite is true as more women are working in later cohorts. It is important to note that the cohort effects get stronger when we include a full set of regressors for men; however, they get dramatically weaker for women (see Model 6 results). This suggests that much more of the change in labor force participation across cohorts for women can be explained by changing education and business cycle effects (unemployment) than is true for men over this period.

For both men and women, age has a large negative impact on participation, and the effects are larger at older ages. On the other hand, workers with greater remaining life expectancy work with higher probability than those with lower RLEs, but these effects decline for larger values of RLE.

In all specifications of the model, either by age or by RLE, the dummy variables indicating age 62 and age 65 have strong, negative effects on labor force participation.

\footnotetext{
${ }^{5}$ When we include age/RLE in the discussion, the reader will note that we mean both the age/RLE variable and its quadratic.
} 
This is true even though the models by age include a quadratic term in age to capture the acceleration in labor force participation declines by age. ${ }^{6}$ These results suggest that there are strong negative effects on working that result from the early retirement age and the normal retirement age under Social Security and from the Medicare eligibility age (currently 65). ${ }^{7}$ We cannot distinguish in this research between what may be the economic effect of getting retirement benefits under the program and the signal effect on retirees that somehow they 'should be' retiring at these ages. Our suspicion, however, is that it is a combination of these effects coming through in the data.

Greater education is associated with higher levels of labor force participation for men and women under all specifications. Participation for all older workers declines in periods with greater unemployment, and their participation is negatively related to the share of the population that is aged 20 to 29 . Interestingly, during years of greater numbers of disabled workers collecting Social Security disability benefits, participation for older workers increases under all specifications except those which control for male remaining life expectancy.

Marital status obviously also matters for labor force participation with married men participating more and married women participating less. The opposite pattern holds for those who never married with men participating less and women participating more than widowed, divorced, or separated individuals.

\footnotetext{
${ }^{6}$ It is also true that we include a quadratic term in remaining life expectancy in the models by RLE.

${ }^{7}$ The Social Security normal retirement age is 66 and older for the later cohorts in our sample (those born in 1943 and later).
} 


\section{Conclusions}

In part, our results confirm what other research has shown, suggesting that labor force participation at older ages is on the rise after roughly 1995 despite the fact that, at least for men, the trend has been strongly negative prior to the 1990s. However, there is no such increase in participation by remaining life expectancy. Participation appears to have flattened out by RLE. This raises the question of whether this is because workers plan for a certain number of years of retirement or because the disutility of work has decreased over time as the US economy has been transformed from a manufacturing economy to a service economy. We also find that whether we specify the empirical model by age or by RLE, the ages 62 and 65 both have strong negative effects on participation, confirming the enormous role Social Security plays in labor supply decisions of older workers. Further research is needed on the question of whether the age 62 and age 65 effects are due to the financial incentives under Social Security or to a signaling effect of those ages under the program. 


\section{References}

Anderson, K.H., and R.V. Burkhauser. 1985. "The Retirement-Health nexus: A New Measure of an Old Puzzle.” Journal of Human Resources. 20(3): 315-330.

Blau, David M., and Donna B. Gilleskie. 2001. "Retiree Health Insurance and the Labor Force Behavior of Older Men in the 1990s.” Review of Economics and Statistics 83(1): 64-80.

— 2003. "The Role of Retiree Health Insurance in the Employment Behavior of Older Men,” NBER Working Paper 10100 (Cambridge, National Bureau of Economic Research).

Blundell, Richard, Costas Meghir, and Sarah Smith. 2002. "Pension Incentives and the Pattern of Early Retirement,” The Economic Journal 112(478): C153-C170.

Bound, John. 1991. "Self-Reported Versus Objective Measures of Health in Retirement Models.” Journal of Human Resources. 26(1): 106-138.

Bound, John, Todd Stinebrickner, and Timothy Waidmann. 2007. "Health, Economic Resources, and the Work Decisions of Older Men,” NBER Working Paper 13657 (Cambridge, National Bureau of Economic Research).

Burtless, Gary, and Robert Moffitt. 1984. "The Effect of Social Security Benefits on the Labor Supply of the Aged,” in H. Aaron and G. Burtless, (Eds.), Retirement and Economic Behavior (Washington: Brookings Institution).

Chan, Sewin, and Ann Huff Stevens. 2004. "Doe Changes in Pension Incentives Affect Retirement? A Longitudinal Study of Subjective Retirement Expectations,” Journal of Public Economics 88(7-8): 1307-1333.

Coile, Courtney C., and Jonathan Gruber. 2000. "Social Security and Retirement,” NBER Working Paper 7830 (Cambridge, National Bureau of Economic Research).

—. 2007. "Future Social Security Entitlements and the Retirement Decision," Review of Economics and Statistics 89(2): 234-246.

Coile, Courtney C., and Phillip B. Levine. 2007. “Labor Market Shocks and Retirement: Do Government Programs Matter?” Journal of Public Economics 91(10): 1902-1919.

Duggan, Mark, Perry Singleton, and Jae Song. 2007. "Aching to Retire? The Rise in the Full Retirement Age and Its Impact on the Social Security Disability Rolls.” Journal of Public Economics 91(7-8): 1327-1350. 
Dwyer, Debra S., and Olivia S. Mitchell. 1999. "Health Problems as Determinants of Retirement: Are Self-Rated Measures Endogenous?” Journal of Health Economics 18(2): 173-193.

Eyster, Lauren, Richard W. Johnson, and Eric J. Toder. 2008. "Current Strategies to Employ and Retain Older Workers,” Urban Institute Research Report (Washington, DC: The Urban Institute).

Fallick, Bruce, and Jonathan Pingle. 2006. "A Cohort-Based Model of Labor Force Participation," Finance and Economics Discussion Series, 2007-09 (Washington, DC: Federal Reserve Board).

Friedberg, Leora, and Anthony Webb. 2005. "Retirement and the Evolution of the Pension Structure,” Journal of Human Resources 40(2): 281-308.

—. 2006. "Persistence in Labor Supply and the Response to the Social Security Earnings Test,” CRR WP 2006-27 (Chestnut Hill: Center for Retirement Research at Boston College).

Gendell, Murray. 2001. "Retirement Age Declines Again in 1990s," Monthly Labor Review 124(10): 12-21.

Goda, Gopi S., John B. Shoven, and Sita N. Slavov. 2007. “A Tax on Work for the Elderly: Medicare as a Secondary Payer.” NBER Working Paper 13383 (Cambridge, National Bureau of Economic Research).

Gruber, Jonathan, and Peter Orszag. 2000. "Does the Social Security Earnings Test Affect Labor Supply and Benefits Receipt?” CRR WP 2000-07 (Chestnut Hill: Center for Retirement Research at Boston College).

Hurd, Michael D., "Research on the Elderly: Economic Status, Retirement, and Consumption and Saving,” Journal of Economic Literature 28 (June 1990), 565-637.

Johnson, Richard W., Amy J. Davidoff, and Kevin Perese. 2003. "Health Insurance Costs and Early Retirement Decisions,” Industrial and Labor Relations Review 56(4): 716-729.

Johnson, Richard W., Gordon B.T. Mermin, and Matthew Resseger. 2007. "Employment at Older Ages and the Changing Nature of Work," Research Report 2007-20 (Washington, DC: AARP).

Manchester, Colleen F. 2007. "The Effect of Pension Plan Type on Retirement Age: Distinguishing Plan Incentives from Career Length Preferences.” Working Paper, Industrial Relations Center, Carlson School of Management, University of Minnesota. 
Rogowski, Jeannette, and Lynn Karoly. 1994. "The Effect of Access to Post-Retirement Health Insurance on the Decision to Retire Early,” Industrial and Labor Relations Review 48(1): 103-123.

— 2000. "Health Insurance and Retirement Behavior: Evidence from the Health and Retirement Survey,” Journal of Health Economics 19(4): 529-539.

Ruhm, Christopher J. 1995. "Secular Changes in the Work and Retirement Patterns of Older Men,” Journal of Human Resources 30(2): 362-385.

Samwick, Andrew. 1998. "New Evidence on Pensions, Social Security, and the Timing of Retirement,” Journal of Public Economics 70(2): 207-236.

Schirle, Tammy. 2008. "Why Have the Labor Force Participation Rates of Older Men Increased Since the Mid-1990s?” Journal of Labor Economics 26(4): 549-594.

Song, Jae G. 2003. "Evaluating the Initial Impact of Eliminating the Retirement Earnings Test,” Social Security Bulletin 65(1): 1-15.

Szafran, Robert F. 2002. “Age-adjusted Labor Force Participation Rates, 1960-2045,” Monthly Labor Review 125(9): 25-38.

Toder, Eric J., Richard W. Johnson, Gordon B.T. Mermin, and Serena Lei. 2008. "Capitalizing on the Value of Older Adults' Work: An Urban Institute Roundtable," The Retirement Policy Program Occasional Paper Number 9. 
Figure 1

Male Labor Force Participation

by Age and Birth Cohort
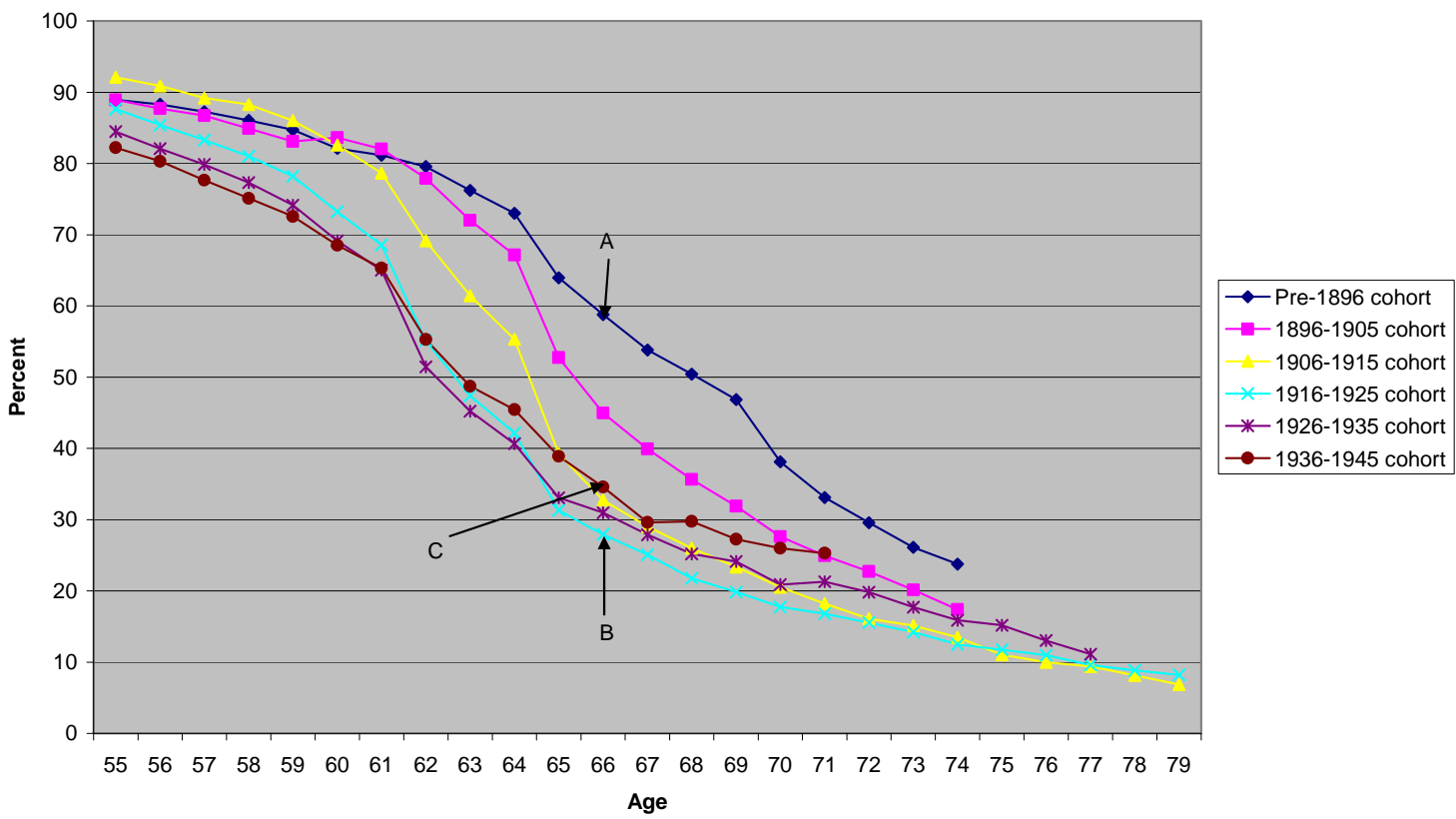

Figure 2

Female Labor Force Participation

by Age and Birth Cohort

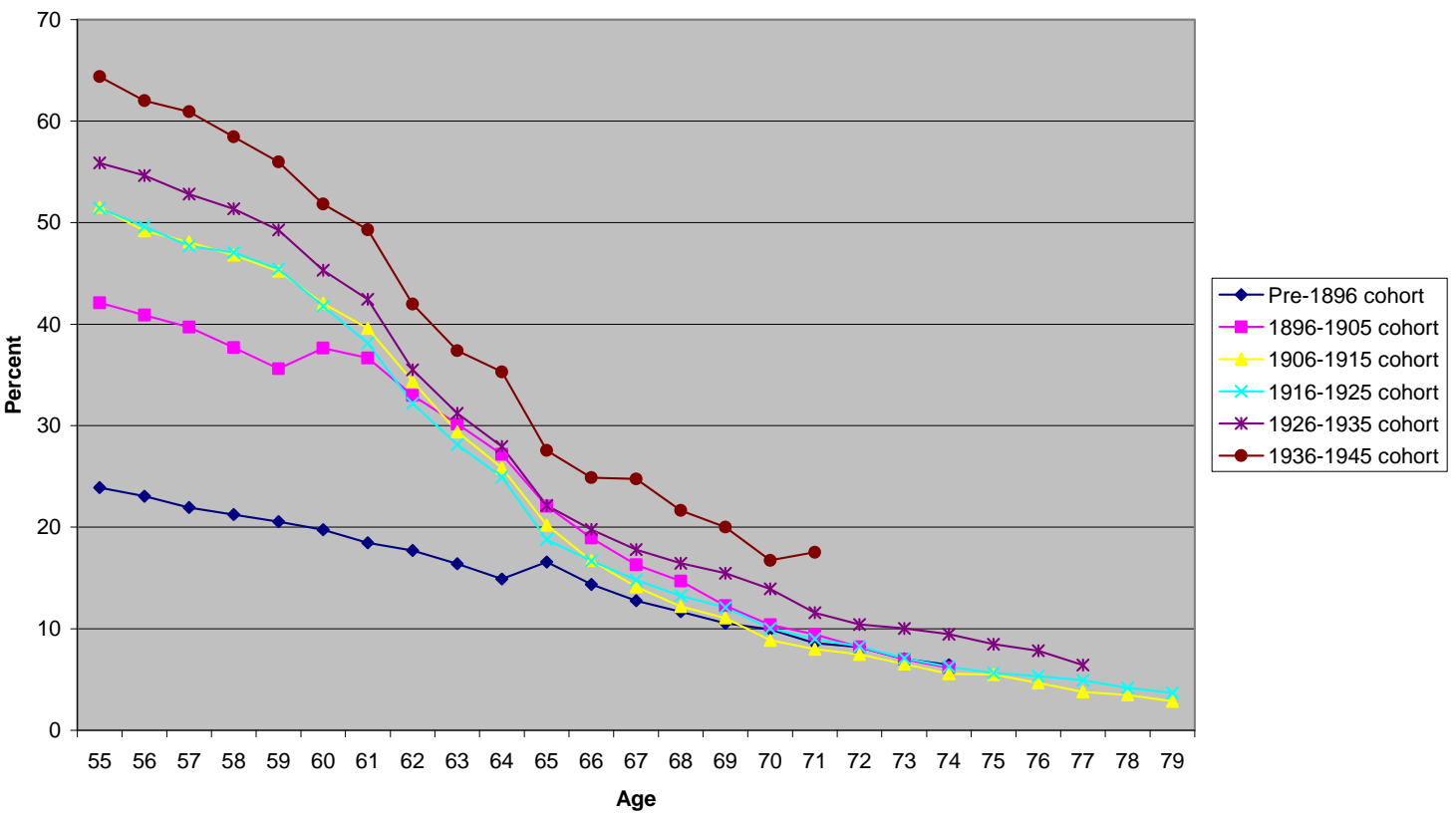


Figure 3

Male Labor Force Participation

by Remaining Life Expectancy and Birth Cohort

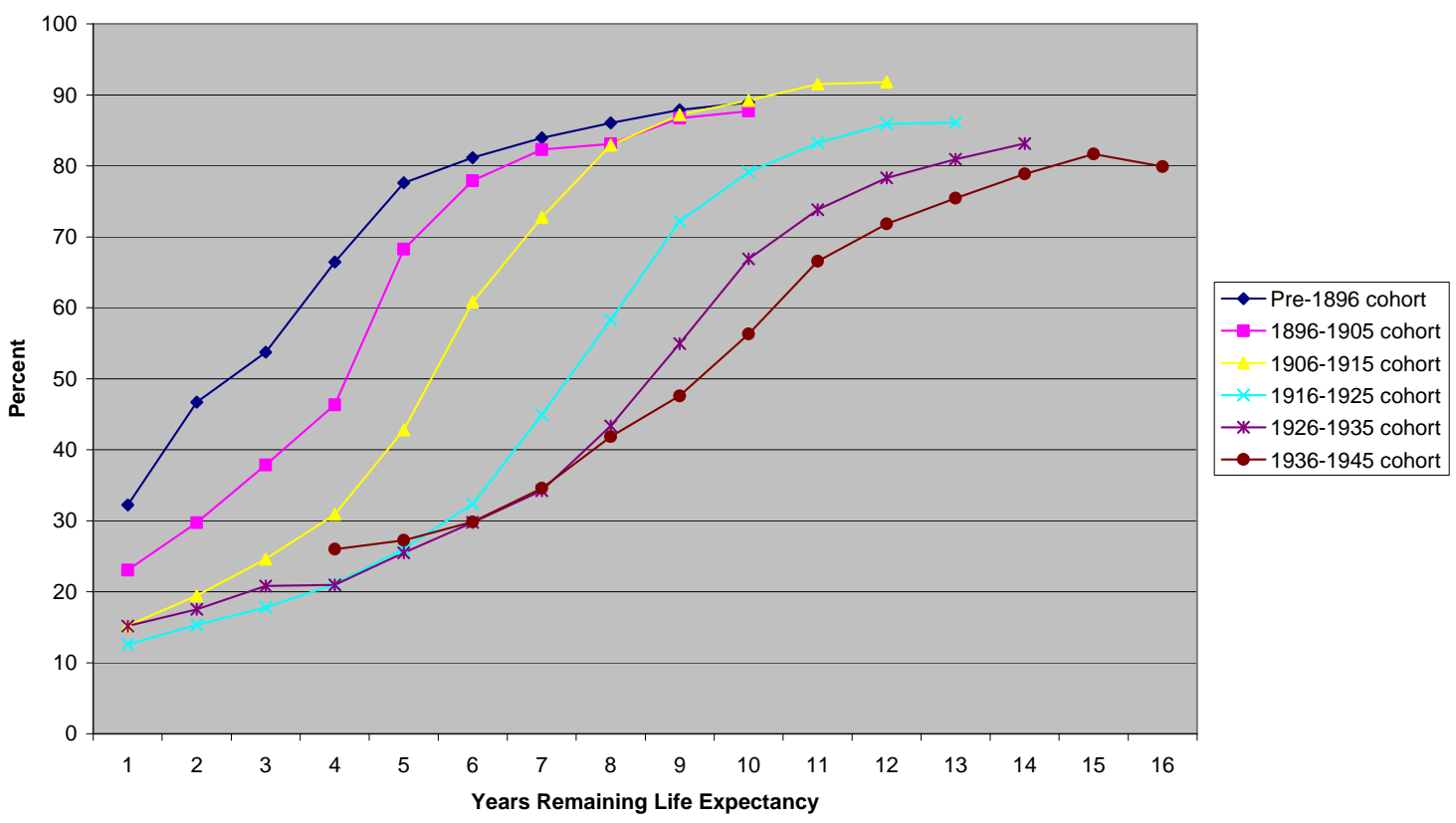

Figure 4

Female Labor Force Participation

by Remaining Life Expectancy and Birth Cohort

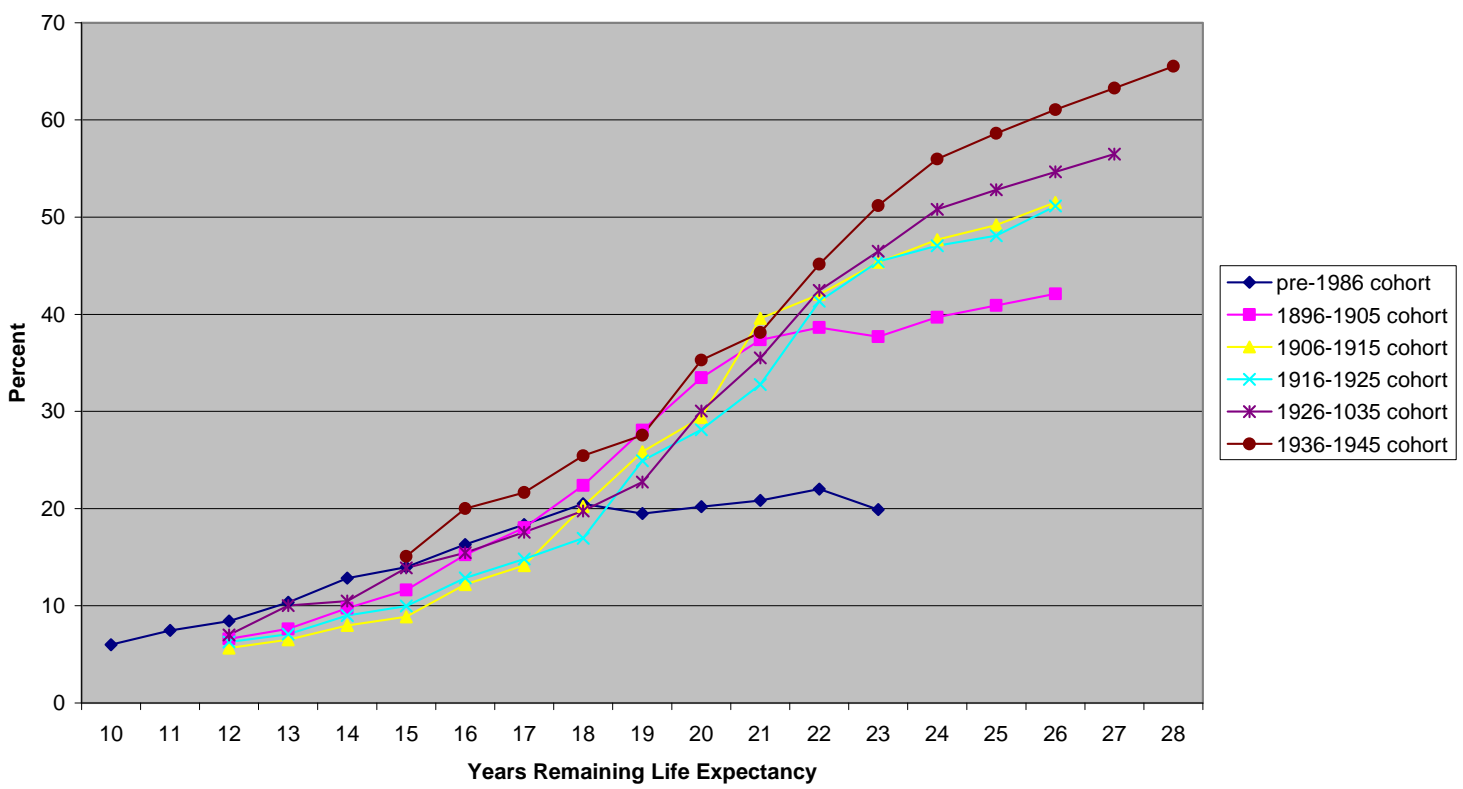




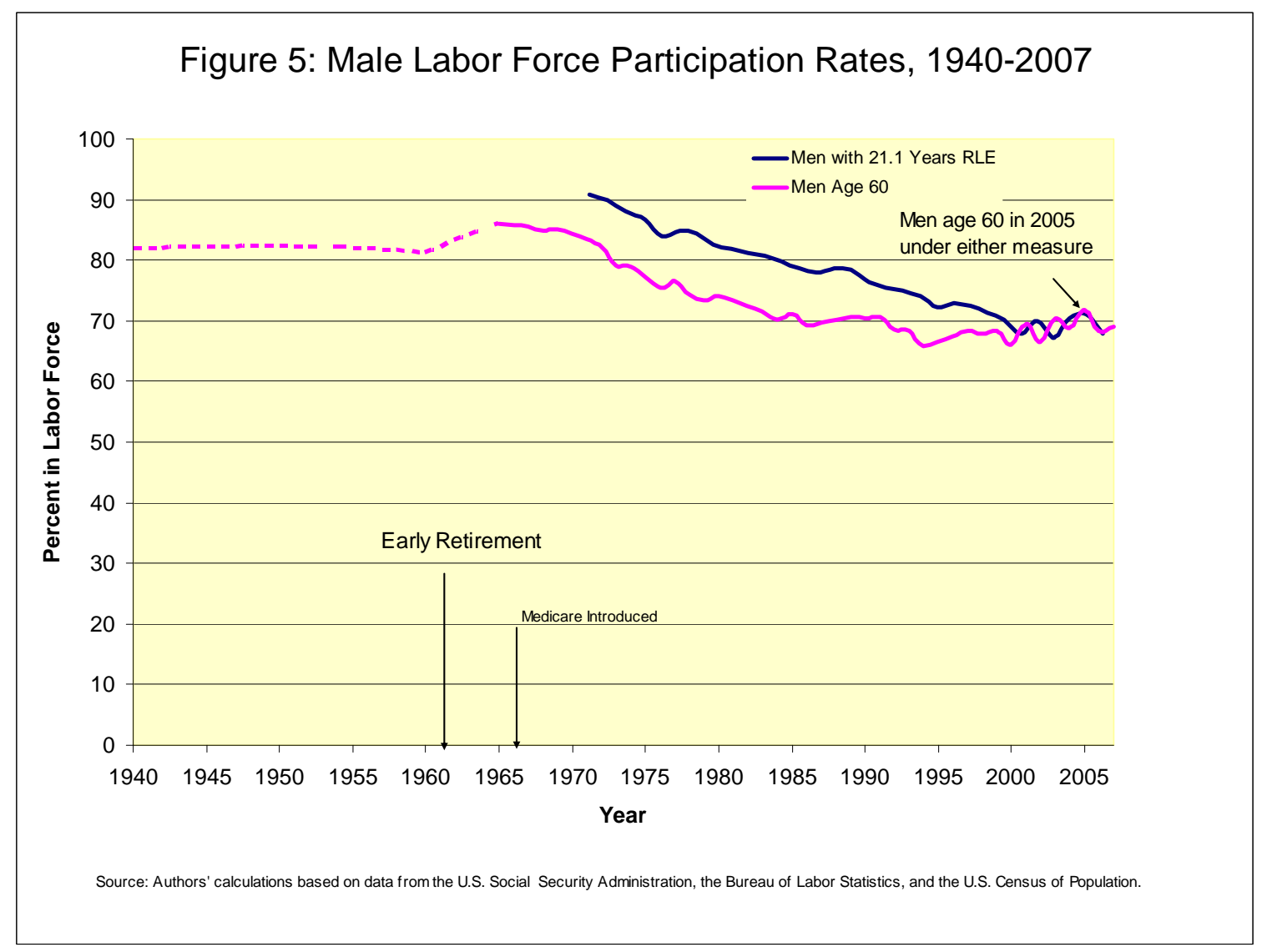




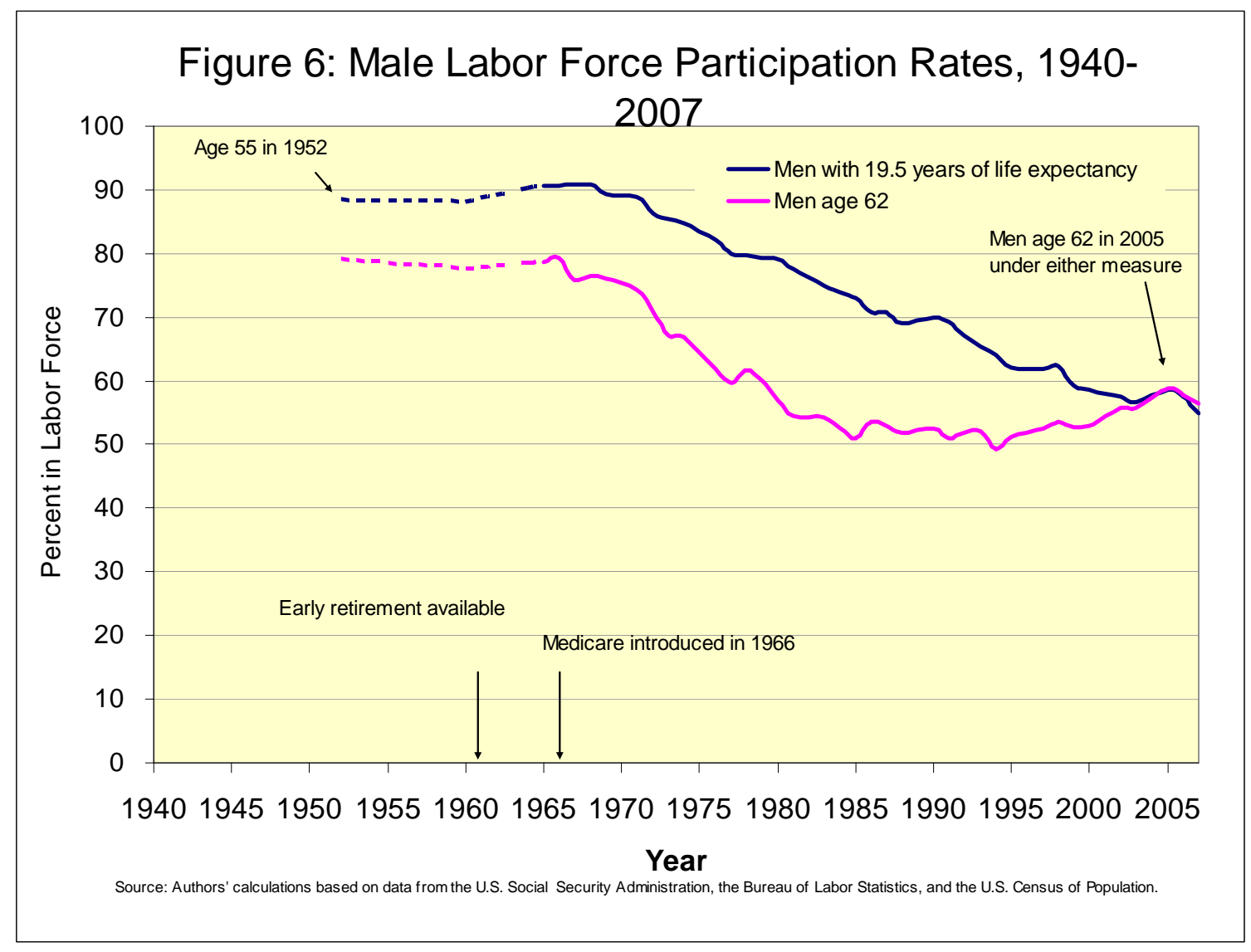




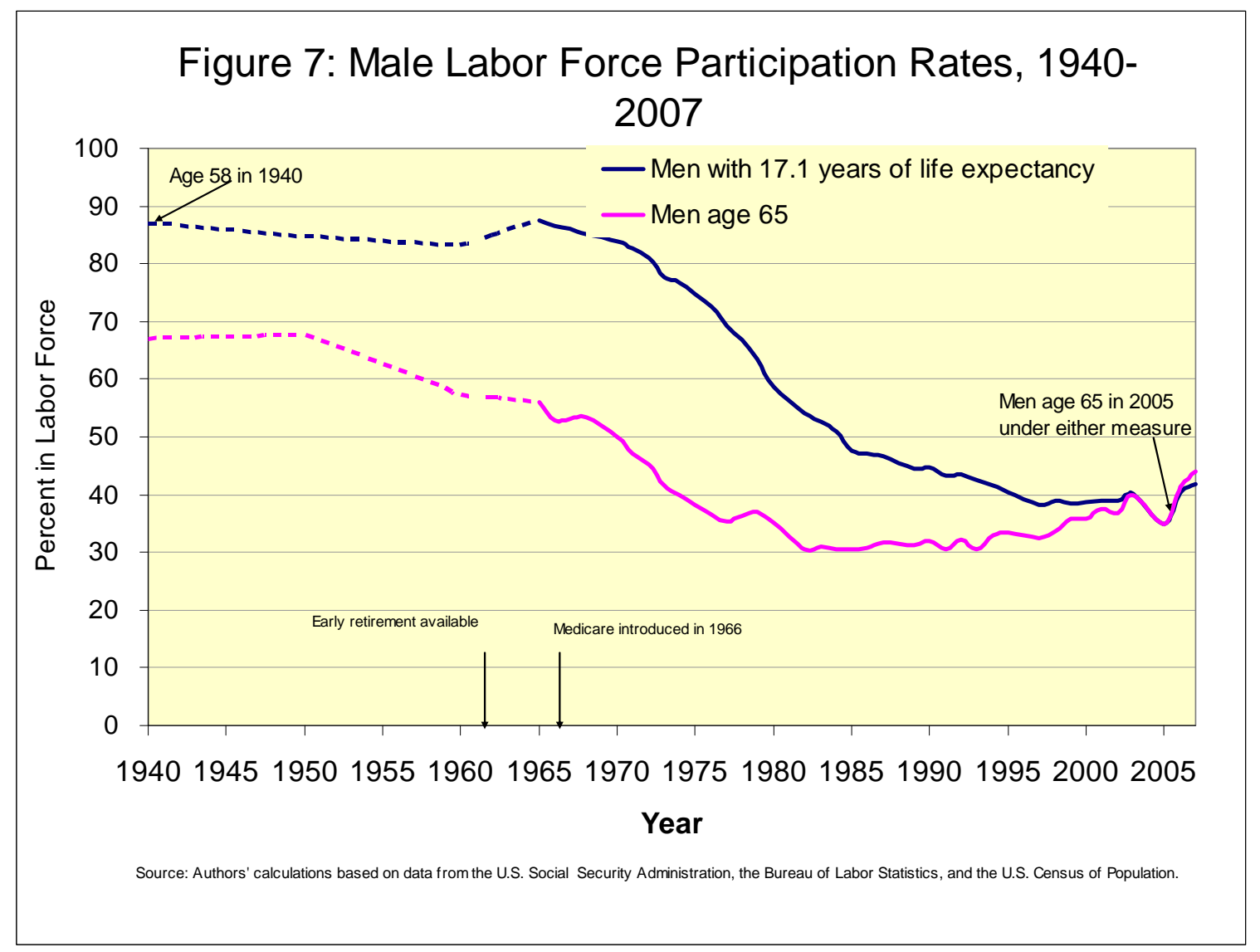



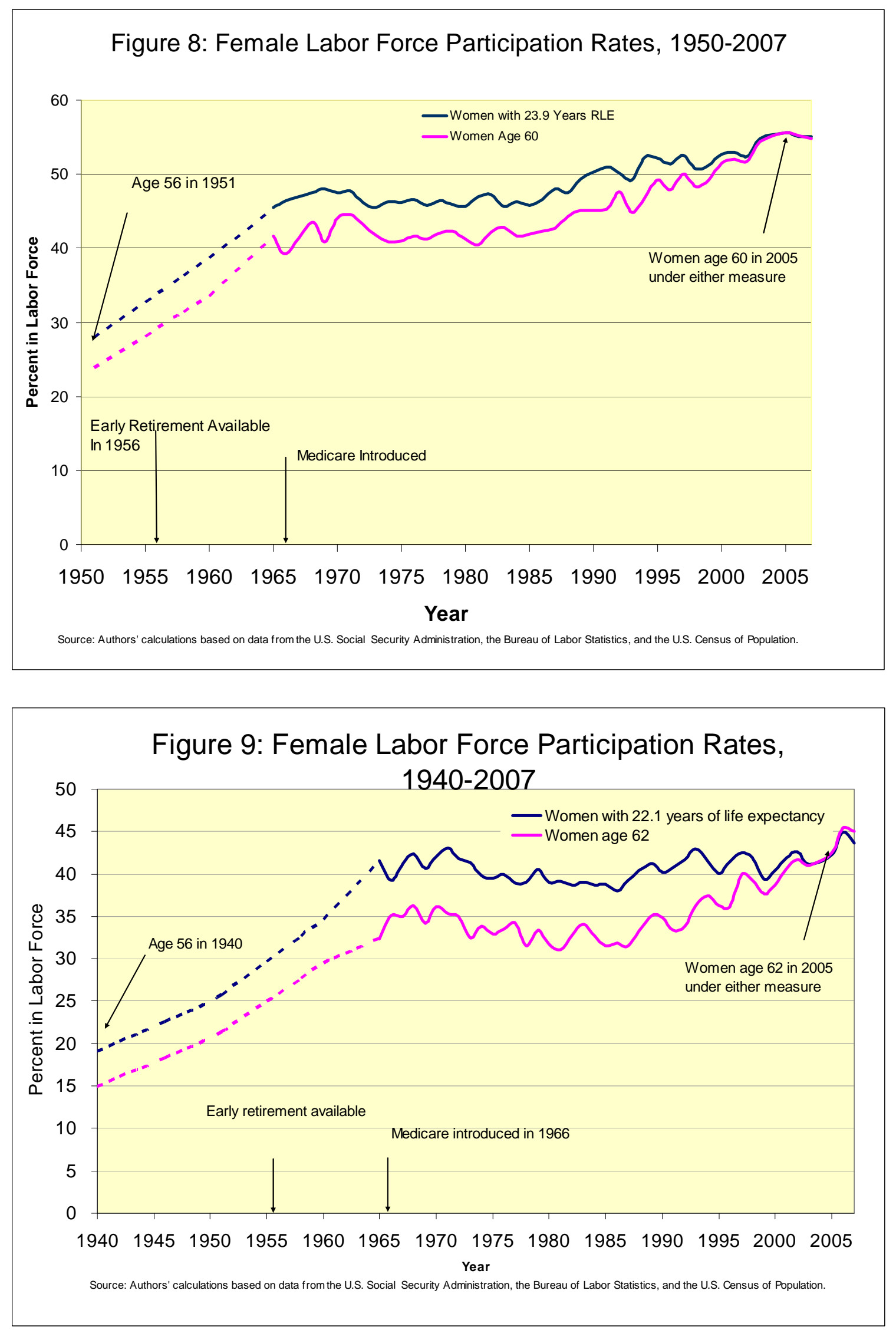


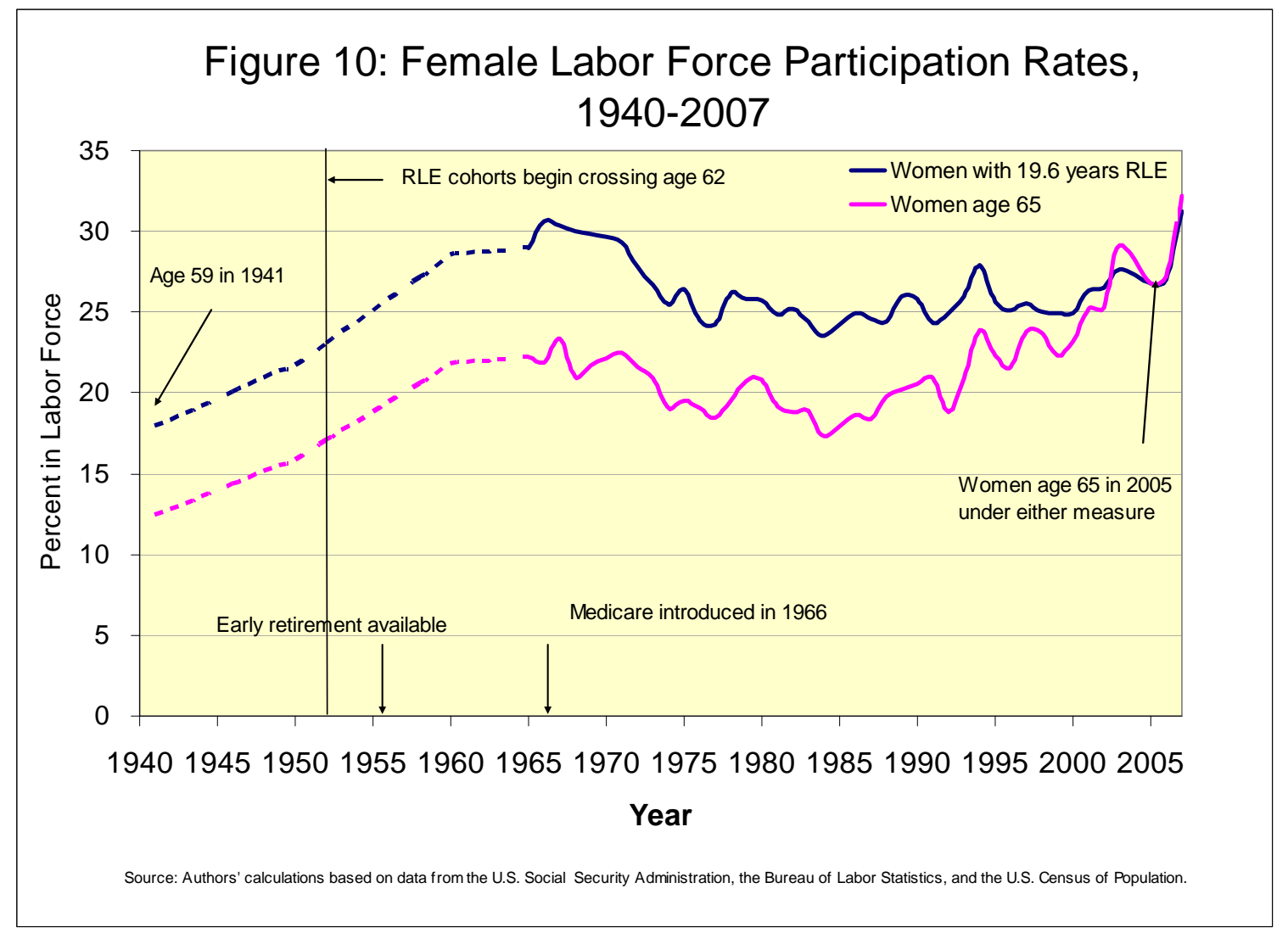

Figure 11: Labor Force Participation of 70-75 Year Old Men by Marital Status

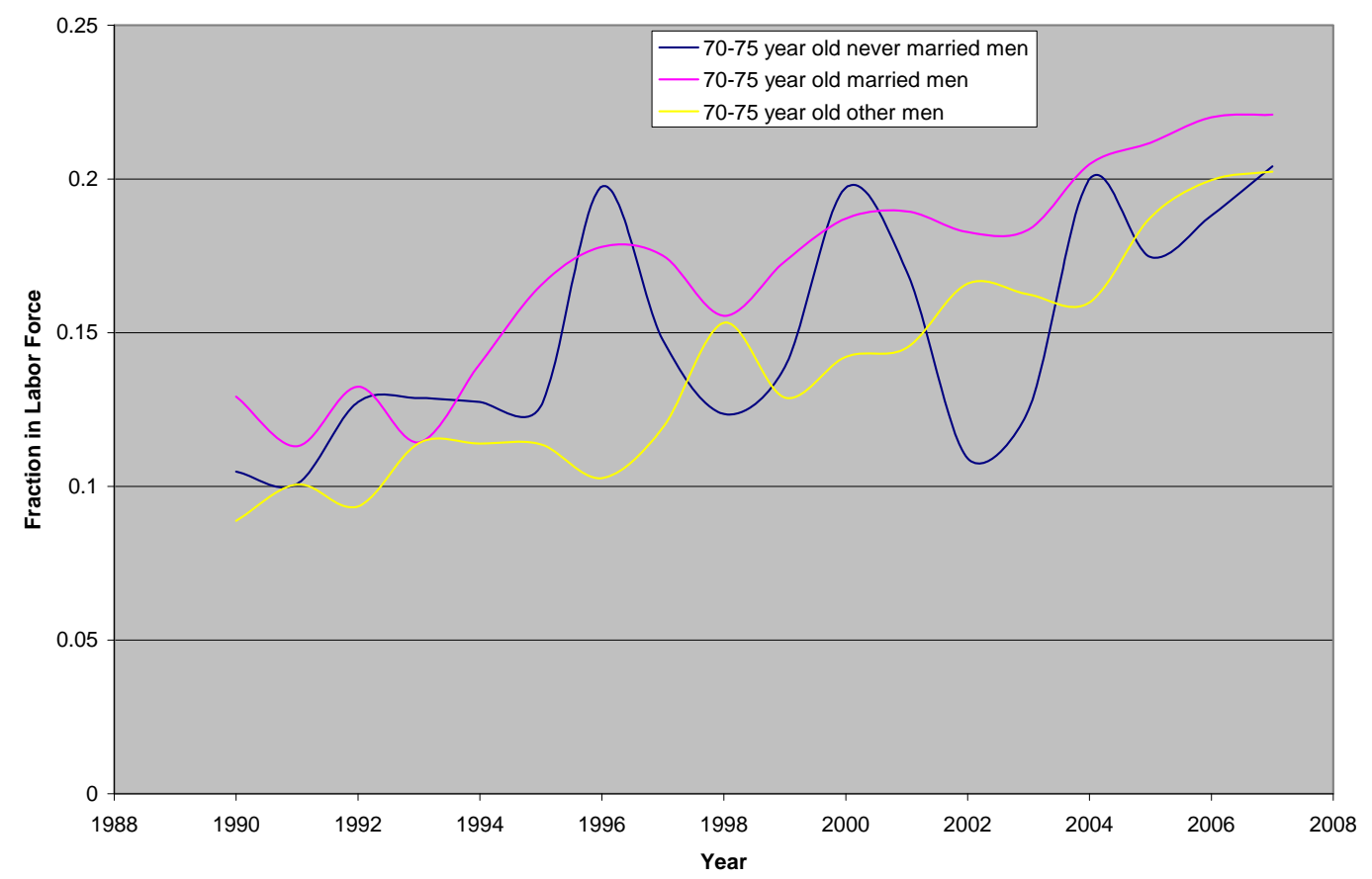


Figure 12: Labor Force Participation of 55-59 Year Old Men by Marital Status

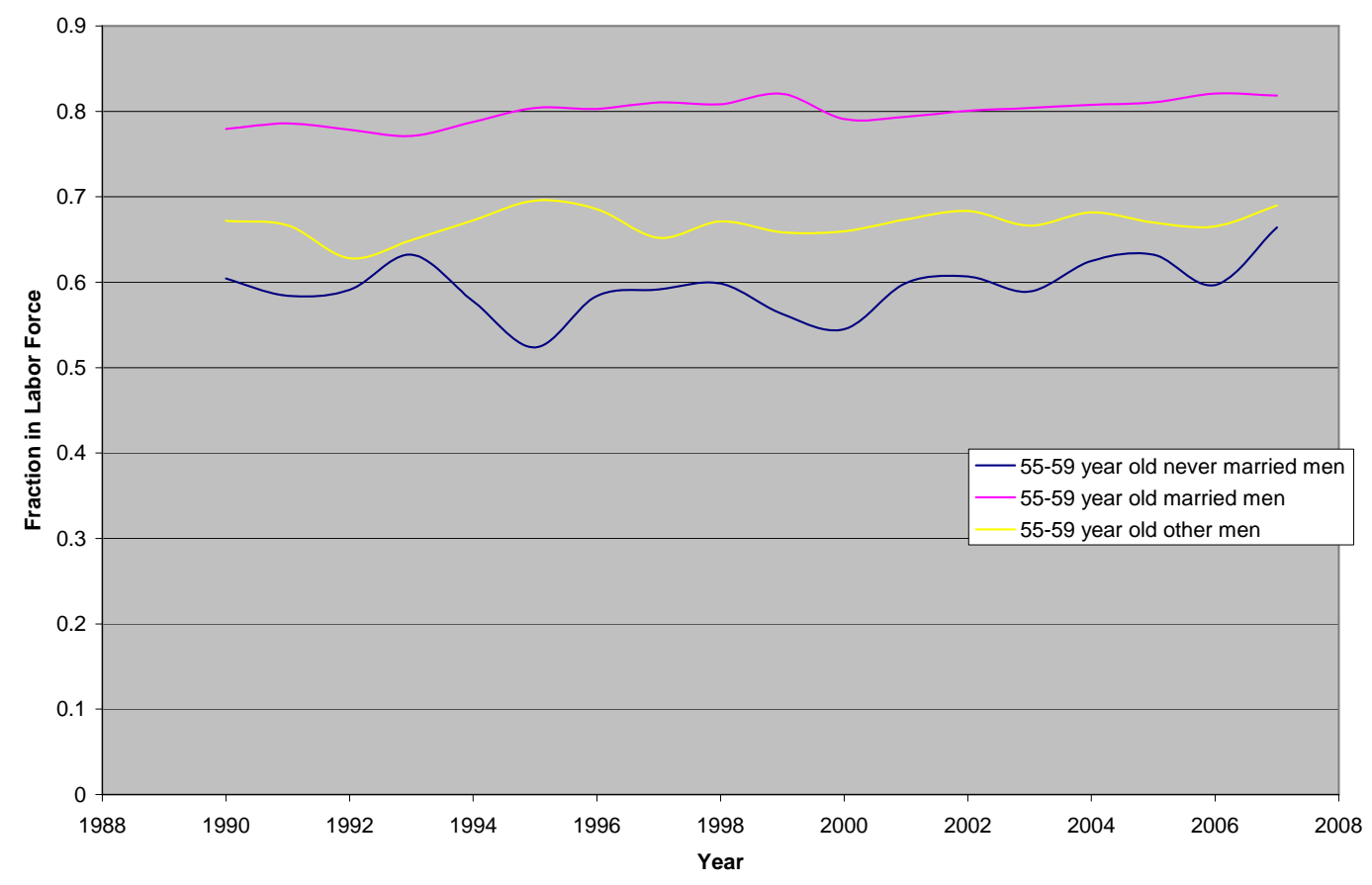




\begin{tabular}{|c|c|c|c|c|c|c|}
\hline Variable & Model 1 & Model 2 & Model 3 & Model 4 & Model 5 & Model 6 \\
\hline Constant & $\begin{array}{c}1.7748^{\star \star \star} \\
(0.008)\end{array}$ & $\begin{array}{c}1.7881^{\star \star \star} \\
(0.008)\end{array}$ & $\begin{array}{c}2.4678^{\star \star \star \star} \\
(0.053)\end{array}$ & $\begin{array}{c}1.3220 \star \star \star \\
(0.011)\end{array}$ & $\begin{array}{c}1.3233^{\star \star \star \star} \\
(0.009)\end{array}$ & $\begin{array}{c}1.7203^{\star \star \star} \\
(0.055)\end{array}$ \\
\hline Age & $\begin{array}{c}-0.1764^{\star \star \star} \\
(0.001)\end{array}$ & $\begin{array}{c}-0.1705^{\star \star \star} \\
(0.001)\end{array}$ & $\begin{array}{c}-0.1846^{\star \star \star} \\
(0.001)\end{array}$ & $\begin{array}{c}-0.1775^{\star \star \star} \\
(0.001)\end{array}$ & $\begin{array}{c}-0.1810 * \star \star \\
(0.001)\end{array}$ & $\begin{array}{c}-0.1815^{\star \star \star} \\
(0.001)\end{array}$ \\
\hline Age Squared & $\begin{array}{c}-0.0016^{\star \star \star} \\
(0.000)\end{array}$ & $\begin{array}{c}-0.0019 * \star \star \\
(0.000)\end{array}$ & $\begin{array}{c}-0.0014^{\star \star \star} \\
(0.000)\end{array}$ & $\begin{array}{c}-0.0015^{\star \star \star} \\
(0.000)\end{array}$ & $\begin{array}{c}-0.0016 * \star \star \\
(0.000)\end{array}$ & $\begin{array}{c}-0.0018^{\star \star \star} \\
(0.000)\end{array}$ \\
\hline 1900 Birth Cohort & $\begin{array}{c}0.4670 * * * \\
(0.013)\end{array}$ & $\begin{array}{c}0.4686^{\star * *} \\
(0.013)\end{array}$ & $\begin{array}{c}0.5997^{\star \star \star} \\
(0.016)\end{array}$ & $\begin{array}{c}0.4540 * * * \\
(0.013)\end{array}$ & $\begin{array}{c}0.7378^{\star \star \star} \\
(0.014)\end{array}$ & $\begin{array}{c}0.7992^{\star * *} \\
(0.017)\end{array}$ \\
\hline 1910 Birth Cohort & $\begin{array}{c}0.2218^{* * *} \\
(0.010)\end{array}$ & $\begin{array}{c}0.2212^{\star \star \star} \\
(0.010)\end{array}$ & $\begin{array}{c}0.3924^{\star \star *} \\
(0.013)\end{array}$ & $\begin{array}{c}0.1988^{\star * *} \\
(0.010)\end{array}$ & $\begin{array}{c}0.4045^{\star \star \star \star} \\
(0.010)\end{array}$ & $\begin{array}{c}0.5108^{* * *} \\
(0.013)\end{array}$ \\
\hline 1920 Birth Cohort & $\begin{array}{l}-0.0041 \\
(0.009)\end{array}$ & $\begin{array}{l}-0.0063 \\
(0.009)\end{array}$ & $\begin{array}{c}0.1279 \star \star \star \\
(0.011)\end{array}$ & $\begin{array}{c}-0.0192^{\star \star} \\
(0.009)\end{array}$ & $\begin{array}{c}0.0751^{\star \star \star} \\
(0.009)\end{array}$ & $\begin{array}{c}0.1637^{* * *} \\
(0.011)\end{array}$ \\
\hline 1940 Birth Cohort & $\begin{array}{c}-0.0704^{\star \star \star} \\
(0.010)\end{array}$ & $\begin{array}{c}-0.0786^{\star \star \star} \\
(0.010)\end{array}$ & $\begin{array}{c}-0.2001^{\star * \star} \\
(0.013)\end{array}$ & $\begin{array}{c}-0.0398^{\star \star \star} \\
(0.010)\end{array}$ & $\begin{array}{c}-0.1782^{\star \star \star} \\
(0.010)\end{array}$ & $\begin{array}{c}-0.2479 * * \star \\
(0.013)\end{array}$ \\
\hline 1950 Birth Cohort & $\begin{array}{c}-0.2716^{\star \star \star} \\
(0.016)\end{array}$ & $\begin{array}{c}-0.2739 * \star \star \\
(0.015)\end{array}$ & $\begin{array}{c}-0.4685^{\star \star \star} \\
(0.020)\end{array}$ & $\begin{array}{c}-0.2036^{\star \star \star} \\
(0.016)\end{array}$ & $\begin{array}{c}-0.4438^{\star \star \star *} \\
(0.016)\end{array}$ & $\begin{array}{c}-0.5089^{\star \star \star} \\
(0.020)\end{array}$ \\
\hline Age 62 & & $\begin{array}{c}-0.0927^{\star \star \star} \\
(0.014)\end{array}$ & & & & $\begin{array}{c}-0.0908^{\star \star \star} \\
(0.014)\end{array}$ \\
\hline Age 65 & & $\begin{array}{c}-0.3877^{\star \star \star} \\
(0.015)\end{array}$ & & & & $\begin{array}{c}-0.4113^{\star \star \star} \\
(0.015)\end{array}$ \\
\hline $\begin{array}{l}\text { Unemployment } \\
\text { Rate }\end{array}$ & & & $\begin{array}{c}-0.0309 * * * \\
(0.003)\end{array}$ & & & $\begin{array}{c}-0.0350 \text { *** } \\
(0.003)\end{array}$ \\
\hline $\begin{array}{l}\text { 20-29 Year Olds } \\
\text { Population Share }\end{array}$ & & & $\begin{array}{c}-4.1837 * * * \\
(0.346)\end{array}$ & & & $\begin{array}{c}-3.9067^{\star \star \star} \\
(0.353)\end{array}$ \\
\hline $\begin{array}{l}\text { SS Disabled } \\
\text { Workers/ 25-64 } \\
\text { Year Olds }\end{array}$ & & & $\begin{array}{c}5.5058^{* * *} \\
(0.802)\end{array}$ & & & $\begin{array}{c}1.5557^{\star * *} \\
(0.8229)\end{array}$ \\
\hline Never Married & & & & $\begin{array}{c}-0.3129 \star \star \star \\
(0.016)\end{array}$ & & $\begin{array}{c}-0.3081^{\star \star \star} \\
(0.106)\end{array}$ \\
\hline Married & & & & $\begin{array}{c}0.5766^{\star \star \star} \\
(0.010)\end{array}$ & & $\begin{array}{c}0.5319 * \star \star \\
(0.010)\end{array}$ \\
\hline $\begin{array}{l}\text { High } \\
\text { SchoolGraduate }\end{array}$ & & & & & $\begin{array}{c}0.4288^{\star \star \star \star} \\
(0.008)\end{array}$ & $\begin{array}{c}0.4087^{\star \star \star} \\
(0.008)\end{array}$ \\
\hline Some College & & & & & $\begin{array}{c}0.6104^{\star \star \star} \\
(0.012)\end{array}$ & $\begin{array}{c}0.5710^{\star \star \star} \\
(0.013)\end{array}$ \\
\hline College Graduate & & & & & $\begin{array}{c}0.9988^{\star * \star} \\
(0.009)\end{array}$ & $\begin{array}{c}0.9659 \text { *** } \\
(0.009)\end{array}$ \\
\hline
\end{tabular}

*** Significant at the 0.01 percent level of significance.

The excluded group is widowed/divorced men/women, 55 years old, from the 1930s cohort with less than a high school diploma. 


\begin{tabular}{|c|c|c|c|c|c|c|}
\hline Variable & Model 1 & Model 2 & Model 3 & Model 4 & Model 5 & Model 6 \\
\hline Constant & $\begin{array}{c}0.3882^{* \star *} \\
(0.007)\end{array}$ & $\begin{array}{c}0.3881^{* * *} \\
(0.007)\end{array}$ & $\begin{array}{c}0.3643^{\star * \star} \\
(0.049) \\
\end{array}$ & $\begin{array}{c}-.8113^{\star \star \star} \\
(0.009) \\
\end{array}$ & $\begin{array}{c}-0.0911^{\star \star \star} \\
(0.009)\end{array}$ & $\begin{array}{c}0.4150^{\star * *} \\
(0.050)\end{array}$ \\
\hline Age & $\begin{array}{c}-0.0756^{\star * \star} \\
(0.001)\end{array}$ & $\begin{array}{c}-0.0706^{* * *} \\
(0.001)\end{array}$ & $\begin{array}{c}-0.0833^{\star \star \star} \\
(0.001)\end{array}$ & $\begin{array}{c}-0.0823^{\star \star \star} \\
(0.001)\end{array}$ & $\begin{array}{c}-0.0795^{\star \star \star} \\
(0.001)\end{array}$ & $\begin{array}{c}-0.0878^{\star \star \star} \\
(0.001)\end{array}$ \\
\hline Age Squared & $\begin{array}{c}-0.0041^{* * *} \\
(0.000)\end{array}$ & $\begin{array}{c}-0.0043^{\star \star *} \\
(0.000)\end{array}$ & $\begin{array}{c}-0.0040^{\star * *} \\
(0.000)\end{array}$ & $\begin{array}{c}-0.0043^{\star * *} \\
(0.000)\end{array}$ & $\begin{array}{c}-0.0040^{* * *} \\
(0.000)\end{array}$ & $\begin{array}{c}-0.0044^{\star * *} \\
(0.000)\end{array}$ \\
\hline 1900 Birth Cohort & $\begin{array}{c}-0.2356^{\star \star *} \\
(0.014)\end{array}$ & $\begin{array}{c}-0.2335^{\star \star *} \\
(0.014)\end{array}$ & $\begin{array}{c}-0.0738^{\star \star *} \\
(0.017)\end{array}$ & $\begin{array}{c}-0.2684^{\star \star \star} \\
(0.014)\end{array}$ & $\begin{array}{c}-0.0269^{*} \\
(0.014)\end{array}$ & $\begin{array}{c}0.0706^{\star \star \star} \\
(0.017)\end{array}$ \\
\hline 1910 Birth Cohort & $\begin{array}{c}-0.2775^{\star \star *} \\
(0.009)\end{array}$ & $\begin{array}{c}-0.2782^{\star * *} \\
(0.009)\end{array}$ & $\begin{array}{c}-0.1637^{\star * *} \\
(0.011)\end{array}$ & $\begin{array}{c}-0.2845^{\star \star \star} \\
(0.009)\end{array}$ & $\begin{array}{c}-0.1309 * * * \\
(0.009)\end{array}$ & $\begin{array}{c}-0.0407^{* \star *} \\
(0.011)\end{array}$ \\
\hline 1920 Birth Cohort & $\begin{array}{c}-0.2528^{\star * \star} \\
(0.008) \\
\end{array}$ & $\begin{array}{c}-0.2535^{\star \star \star} \\
(0.008)\end{array}$ & $\begin{array}{c}-0.1727^{\star * *} \\
(0.010)\end{array}$ & $\begin{array}{c}-0.2499 * \star * \\
(0.008)\end{array}$ & $\begin{array}{c}-0.1881^{* * *} \\
(0.008)\end{array}$ & $\begin{array}{c}-0.1138^{* * *} \\
(0.010)\end{array}$ \\
\hline 1940 Birth Cohort & $\begin{array}{c}0.3956^{\star \star *} \\
(0.009)\end{array}$ & $\begin{array}{c}0.3917^{\star * *} \\
(0.009)\end{array}$ & $\begin{array}{c}0.2477^{* \star *} \\
(0.012)\end{array}$ & $\begin{array}{c}0.3769 * \star * \\
(0.010)\end{array}$ & $\begin{array}{c}0.2919 * \star * \\
(0.010)\end{array}$ & $\begin{array}{c}0.1483^{\star \star \star} \\
(0.013)\end{array}$ \\
\hline 1950 Birth Cohort & $\begin{array}{c}0.5961^{\star * *} \\
(0.018)\end{array}$ & $\begin{array}{c}0.5949 * \star \star \\
(0.018)\end{array}$ & $\begin{array}{c}0.3652^{\star * *} \\
(0.022)\end{array}$ & $\begin{array}{c}0.5633^{\star \star \star} \\
(0.018)\end{array}$ & $\begin{array}{c}0.4243^{\star * \star} \\
(0.018)\end{array}$ & $\begin{array}{c}0.2064^{\star \star \star} \\
(0.022)\end{array}$ \\
\hline Age 62 & & $\begin{array}{c}-0.0490 \star \star \star \\
(0.014) \\
\end{array}$ & & & & $\begin{array}{c}-0.0400^{\star \star *} \\
(0.014)\end{array}$ \\
\hline Age 65 & & $\begin{array}{c}-0.2526 \text { *** } \\
(0.016)\end{array}$ & & & & $\begin{array}{c}-0.2715^{\star \star \star} \\
(0.016)\end{array}$ \\
\hline $\begin{array}{l}\text { Unemployment } \\
\text { Rate }\end{array}$ & & & $\begin{array}{l}-0.0014 \\
(0.003)\end{array}$ & & & $\begin{array}{l}-0.0056^{*} \\
(0.003) \\
\end{array}$ \\
\hline $\begin{array}{l}\text { 20-29 Year Olds } \\
\text { Population Share }\end{array}$ & & & $\begin{array}{c}-1.8149 * * * \\
(0.325)\end{array}$ & & & $\begin{array}{c}-1.6750^{\star * \star} \\
(0.332)\end{array}$ \\
\hline $\begin{array}{l}\text { SS Disabled } \\
\text { Workers/ 25-64 } \\
\text { Year Olds }\end{array}$ & & & $\begin{array}{c}12.1794 * * * \\
(0.780)\end{array}$ & & & $\begin{array}{c}8.9586^{\star * *} \\
(0.800)\end{array}$ \\
\hline Never Married & & & & $\begin{array}{c}0.1330^{* \star *} \\
(0.014) \\
\end{array}$ & & $\begin{array}{c}0.0519 * \star \star \\
(0.014)\end{array}$ \\
\hline Married & & & & $\begin{array}{c}-0.5542^{\star \star \star} \\
(0.007)\end{array}$ & & $\begin{array}{c}-0.6174^{\star \star *} \\
(0.007)\end{array}$ \\
\hline $\begin{array}{l}\text { High } \\
\text { SchoolGraduate }\end{array}$ & & & & & $\begin{array}{c}0.5152^{\star \star *} \\
(0.007)\end{array}$ & $\begin{array}{c}0.5662^{\star \star \star} \\
(0.007)\end{array}$ \\
\hline Some College & & & & & 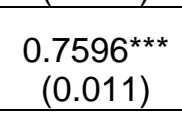 & $\begin{array}{c}0.7802^{\star \star \star} \\
(0.012)\end{array}$ \\
\hline College Graduate & & & & & $\begin{array}{c}0.9455^{\star * *} \\
(0.009)\end{array}$ & $\begin{array}{c}0.9850 * \star * \\
(0.009)\end{array}$ \\
\hline
\end{tabular}

*** Significant at the 0.01 percent level of significance.

The excluded group is widowed/divorced men/women, 55 years old, from the 1930s

cohort with less than a high school diploma. 


\begin{tabular}{|c|c|c|c|c|c|c|}
\hline Variable & Model 1 & Model 2 & Model 3 & Model 4 & Model 5 & Model 6 \\
\hline Constant & $\begin{array}{c}-8.6936^{* * *} \\
(0.050)\end{array}$ & $\begin{array}{c}-8.7316^{\star * *} \\
(0.051)\end{array}$ & $\begin{array}{c}-7.7530^{* * *} \\
(0.076) \\
\end{array}$ & $\begin{array}{c}-9.1523^{\star \star *} \\
(0.052) \\
\end{array}$ & $\begin{array}{c}-9.4410^{* * *} \\
(0.052) \\
\end{array}$ & $\begin{array}{c}-8.8281^{\star \star \star} \\
(0.078)\end{array}$ \\
\hline RLE & $\begin{array}{c}0.6610 * \star * \\
(0.005)\end{array}$ & $\begin{array}{c}0.6718^{\star \star *} \\
(0.005)\end{array}$ & $\begin{array}{c}0.65424^{\star \star \star} \\
(0.005)\end{array}$ & $\begin{array}{c}0.6584^{\star * *} \\
(0.005)\end{array}$ & $\begin{array}{c}0.6802^{\star \star *} \\
(0.005)\end{array}$ & $\begin{array}{c}0.6798^{\star \star *} \\
(0.005)\end{array}$ \\
\hline RLE Squared & $\begin{array}{c}-0.0095^{\star \star *} \\
(0.000)\end{array}$ & $\begin{array}{c}-0.0098^{\star \star *} \\
(0.000)\end{array}$ & $\begin{array}{c}-0.0093^{\star \star *} \\
(0.000)\end{array}$ & $\begin{array}{c}-0.0094^{* * *} \\
(0.000)\end{array}$ & $\begin{array}{c}-0.0098^{\star * *} \\
(0.000)\end{array}$ & $\begin{array}{c}-0.0099 * \star \star \\
(0.000)\end{array}$ \\
\hline 1900 Birth Cohort & $\begin{array}{c}1.4383^{\star \star *} \\
(0.015)\end{array}$ & $\begin{array}{c}1.4375^{\star \star *} \\
(0.015)\end{array}$ & $\begin{array}{c}1.4194^{\star * *} \\
(0.020)\end{array}$ & $\begin{array}{c}1.4256^{* \star *} \\
(0.015)\end{array}$ & $\begin{array}{c}1.7454^{\star \star \star} \\
(0.016)\end{array}$ & $\begin{array}{c}1.6519 * * \star \\
(0.020)\end{array}$ \\
\hline 1910 Birth Cohort & $\begin{array}{c}0.8961^{\star * *} \\
(0.010)\end{array}$ & $\begin{array}{c}0.8913^{\star \star \star} \\
(0.010) \\
\end{array}$ & $\begin{array}{c}0.9767^{\star * *} \\
(0.014)\end{array}$ & $\begin{array}{c}0.8734^{\star \star *} \\
(0.010)\end{array}$ & $\begin{array}{c}1.1044^{\star \star \star} \\
(0.011)\end{array}$ & $\begin{array}{c}1.1126^{\star \star \star} \\
(0.015)\end{array}$ \\
\hline 1920 Birth Cohort & $\begin{array}{c}0.3135^{\star \star \star} \\
(0.009)\end{array}$ & $\begin{array}{c}0.3067^{\star \star *} \\
(0.009) \\
\end{array}$ & $\begin{array}{c}0.3838^{* \star *} \\
(0.011) \\
\end{array}$ & $\begin{array}{c}0.2986^{\star * *} \\
(0.009) \\
\end{array}$ & $\begin{array}{c}0.4076^{\star \star \star} \\
(0.009) \\
\end{array}$ & $\begin{array}{c}0.4279 * * * \\
(0.012) \\
\end{array}$ \\
\hline 1940 Birth Cohort & $\begin{array}{c}-0.3271^{\star * *} \\
(0.010)\end{array}$ & $\begin{array}{c}-0.3265^{\star \star *} \\
(0.010)\end{array}$ & $\begin{array}{c}-0.3733^{* \star *} \\
(0.013)\end{array}$ & $\begin{array}{c}-0.2969 * * * \\
(0.010)\end{array}$ & $\begin{array}{c}-0.4354^{\star * *} \\
(0.011)\end{array}$ & $\begin{array}{c}-0.4177^{\star \star *} \\
(0.014)\end{array}$ \\
\hline 1950 Birth Cohort & $\begin{array}{c}-0.5183^{* * *} \\
(0.017)\end{array}$ & $\begin{array}{c}-0.5054^{\star \star \star} \\
(0.017)\end{array}$ & $\begin{array}{c}-0.5776^{\star \star \star} \\
(0.022)\end{array}$ & $\begin{array}{c}-0.4526^{* \star *} \\
(0.017)\end{array}$ & $\begin{array}{c}-0.6903^{\star \star *} \\
(0.017)\end{array}$ & $\begin{array}{c}-0.6083^{\star \star \star} \\
(0.023)\end{array}$ \\
\hline Age 62 & & $\begin{array}{c}-0.1244^{\star \star *} \\
(0.014) \\
\end{array}$ & & & & $\begin{array}{c}-0.1207^{\star \star \star} \\
(0.014)\end{array}$ \\
\hline Age 65 & & $\begin{array}{c}-0.3704^{\star \star \star} \\
(0.015)\end{array}$ & & & & $\begin{array}{c}-0.3884^{\star \star *} \\
(0.015)\end{array}$ \\
\hline $\begin{array}{l}\text { Unemployment } \\
\text { Rate }\end{array}$ & & & $\begin{array}{c}-0.0322^{\star \star \star} \\
(0.003)\end{array}$ & & & $\begin{array}{c}-0.0349 \star \star \star \\
(0.003)\end{array}$ \\
\hline $\begin{array}{l}\text { 20-29 Year Olds } \\
\text { Population Share }\end{array}$ & & & $\begin{array}{c}-3.7558^{\star \star \star} \\
(0.3526) \\
\end{array}$ & & & $\begin{array}{c}-3.4389 * \star \star \\
(0.360) \\
\end{array}$ \\
\hline $\begin{array}{l}\text { SS Disabled } \\
\text { Workers/ 25-64 } \\
\text { Year Olds }\end{array}$ & & & $\begin{array}{c}-4.6857^{\star \star \star} \\
(0.846)\end{array}$ & & & $\begin{array}{c}-7.9145^{\star \star \star} \\
(0.863)\end{array}$ \\
\hline Never Married & & & & $\begin{array}{c}-0.3003^{\star * *} \\
(0.016) \\
\end{array}$ & & $\begin{array}{c}-0.2957^{\star \star \star} \\
(0.016)\end{array}$ \\
\hline Married & & & & $\begin{array}{c}0.5987^{\star \star \star} \\
(0.010)\end{array}$ & & $\begin{array}{c}0.5541^{\star \star *} \\
(0.010)\end{array}$ \\
\hline $\begin{array}{l}\text { High } \\
\text { SchoolGraduate }\end{array}$ & & & & & $\begin{array}{c}0.4320 * * * \\
(0.008)\end{array}$ & $\begin{array}{c}0.4118^{\star \star \star} \\
(0.008)\end{array}$ \\
\hline Some College & & & & & $\begin{array}{c}0.6035^{\star \star \star} \\
(0.013)\end{array}$ & $\begin{array}{c}0.5713^{\star \star \star} \\
(0.013)\end{array}$ \\
\hline College Graduate & & & & & $\begin{array}{c}1.0051^{\star \star \star} \\
(0.009)\end{array}$ & $\begin{array}{c}0.9733^{\star * *} \\
(0.009)\end{array}$ \\
\hline
\end{tabular}

*** Significant at the 0.01 percent level of significance.

The excluded group is widowed/divorced men/women, 55 years old, from the 1930s

cohort with less than a high school diploma. 


\begin{tabular}{|c|c|c|c|c|c|c|}
\hline Variable & Model 1 & Model 2 & Model 3 & Model 4 & Model 5 & Model 6 \\
\hline Constant & $\begin{array}{c}-8.0035^{\star \star *} \\
(0.065)\end{array}$ & $\begin{array}{c}-8.0887^{\star \star *} \\
(0.066)\end{array}$ & $\begin{array}{c}-8.0608^{* * *} \\
(0.082)\end{array}$ & $\begin{array}{c}-8.1807^{\star * \star} \\
(0.065)\end{array}$ & $\begin{array}{c}-8.5607^{* * *} \\
(0.066)\end{array}$ & $\begin{array}{c}-0.7796^{\star * *} \\
(0.085)\end{array}$ \\
\hline RLE & $\begin{array}{c}0.5162^{\star \star \star} \\
(0.006)\end{array}$ & $\begin{array}{c}0.5278^{\star \star \star} \\
(0.006)\end{array}$ & $\begin{array}{c}0.5173 * * * \\
(0.006)\end{array}$ & $\begin{array}{c}0.5522^{\star \star \star} \\
(0.006)\end{array}$ & $\begin{array}{c}0.5179 * \star \star \\
(0.006)\end{array}$ & $\begin{array}{c}0.5692^{\star \star \star} \\
(0.006)\end{array}$ \\
\hline RLE Squared & $\begin{array}{c}-0.0078^{\star \star *} \\
(0.000)\end{array}$ & $\begin{array}{c}-0.0080 * \star * \\
(0.000)\end{array}$ & $\begin{array}{c}-0.0076^{\star \star *} \\
(0.000)\end{array}$ & $\begin{array}{c}-0.0083^{\star \star \star} \\
(0.000) \\
\end{array}$ & $\begin{array}{c}-0.0077^{\star * *} \\
(0.000)\end{array}$ & $\begin{array}{c}-0.0085^{\star \star \star} \\
(0.000)\end{array}$ \\
\hline 1900 Birth Cohort & $\begin{array}{c}-0.0894^{\star * *} \\
(0.014) \\
\end{array}$ & $\begin{array}{c}-0.0887^{\star * *} \\
(0.014) \\
\end{array}$ & $\begin{array}{l}0.0126 \\
(0.017) \\
\end{array}$ & $\begin{array}{c}-0.1119 * \star * \\
(0.014)\end{array}$ & $\begin{array}{c}0.1208^{\star \star \star} \\
(0.014)\end{array}$ & $\begin{array}{c}0.1609 * \star \star \\
(0.017)\end{array}$ \\
\hline 1910 Birth Cohort & $\begin{array}{c}-0.1743^{\star * *} \\
(0.009)\end{array}$ & $\begin{array}{c}-0.1770^{\star \star \star *} \\
(0.009)\end{array}$ & $\begin{array}{c}-0.0966^{\star \star *} \\
(0.011)\end{array}$ & $\begin{array}{c}-0.1739 * * * \\
(0.009)\end{array}$ & $\begin{array}{c}-0.0253^{\star * *} \\
(0.009)\end{array}$ & $\begin{array}{c}0.0282^{\star *} \\
(0.012)\end{array}$ \\
\hline 1920 Birth Cohort & $\begin{array}{c}-0.1963^{* * *} \\
(0.008)\end{array}$ & $\begin{array}{c}-0.1984^{* \star *} \\
(0.008)\end{array}$ & $\begin{array}{c}-0.1380 * * \star \\
(0.010)\end{array}$ & $\begin{array}{c}-0.1892^{\star * \star} \\
(0.008)\end{array}$ & $\begin{array}{c}-0.1294^{\star * *} \\
(0.008)\end{array}$ & $\begin{array}{c}-0.0780 * * * \\
(0.010)\end{array}$ \\
\hline 1940 Birth Cohort & $\begin{array}{c}0.3133^{\star \star \star} \\
(0.009)\end{array}$ & $\begin{array}{c}0.3127^{\star * \star} \\
(0.009)\end{array}$ & $\begin{array}{c}0.2166^{\star * \star} \\
(0.013)\end{array}$ & $\begin{array}{c}0.2876^{\star \star \star} \\
(0.010)\end{array}$ & $\begin{array}{c}0.2086^{\star * *} \\
(0.010)\end{array}$ & $\begin{array}{c}0.1182^{* * *} \\
(0.013)\end{array}$ \\
\hline 1950 Birth Cohort & $\begin{array}{c}0.5086^{\star \star \star} \\
(0.018)\end{array}$ & $\begin{array}{c}0.5148^{\star \star \star} \\
(0.018)\end{array}$ & $\begin{array}{c}0.3569 * * * \\
(0.023)\end{array}$ & $\begin{array}{c}0.4684^{* * *} \\
(0.018)\end{array}$ & $\begin{array}{c}0.3349 * \star \star \\
(0.018)\end{array}$ & $\begin{array}{c}0.2073^{\star * *} \\
(0.023)\end{array}$ \\
\hline Age 62 & & $\begin{array}{c}-0.0427^{\star \star * *} \\
(0.014)\end{array}$ & & & & $\begin{array}{c}-0.0350^{* *} \\
(0.014)\end{array}$ \\
\hline Age 65 & & $\begin{array}{c}-0.2359 * \star \star \\
(0.016)\end{array}$ & & & & $\begin{array}{c}-0.2536 * \star \star \\
(0.016)\end{array}$ \\
\hline $\begin{array}{l}\text { Unemployment } \\
\text { Rate }\end{array}$ & & & $\begin{array}{r}-0.0022 \\
(0.003) \\
\end{array}$ & & & $\begin{array}{c}-0.0063^{\star \star} \\
(0.003)\end{array}$ \\
\hline $\begin{array}{l}\text { 20-29 Year Olds } \\
\text { Population Share }\end{array}$ & & & $\begin{array}{c}-1.4261^{\star * *} \\
(0.325)\end{array}$ & & & $\begin{array}{c}-1.2360^{* * *} \\
(0.331)\end{array}$ \\
\hline $\begin{array}{l}\text { SS Disabled } \\
\text { Workers/ 25-64 } \\
\text { Year Olds }\end{array}$ & & & $\begin{array}{c}7.1611^{\star * \star} \\
(0.778) \\
\end{array}$ & & & $\begin{array}{c}3.4143^{\star \star *} \\
(0.798) \\
\end{array}$ \\
\hline Never Married & & & & $\begin{array}{c}0.1335^{\star \star *} \\
(0.014)\end{array}$ & & $\begin{array}{c}0.0531^{\star * *} \\
(0.014)\end{array}$ \\
\hline Married & & & & $\begin{array}{c}-0.5566^{\star * *} \\
(0.007)\end{array}$ & & $\begin{array}{c}-0.6180^{* * *} \\
(0.007)\end{array}$ \\
\hline $\begin{array}{l}\text { High } \\
\text { SchoolGraduate }\end{array}$ & & & & & $\begin{array}{c}0.5119 * \star * \\
(0.007)\end{array}$ & $\begin{array}{c}0.5639 * * * \\
(0.007)\end{array}$ \\
\hline Some College & & & & & $\begin{array}{c}0.7517^{\star \star *} \\
(0.011)\end{array}$ & $\begin{array}{c}0.7773^{* * *} \\
(0.012)\end{array}$ \\
\hline College Graduate & & & & & $\begin{array}{c}0.9409 * * * \\
(0.009)\end{array}$ & $\begin{array}{l}0.9821 \\
(0.009)\end{array}$ \\
\hline
\end{tabular}

*** Significant at the 0.01 percent level of significance.

The excluded group is widowed/divorced men/women, 55 years old, from the 1930s

cohort with less than a high school diploma. 


\section{RECENT WORKING PAPERS FROM THE}

\section{CENTER FOR RETIREMENT RESEARCH AT BOSTON COLLEGE}

Economic Restructuring and Retirement in Urban China

John Giles, January 2009

Sources of Support for Pension Reform: A Cross-National Perspective

Michelle Dion and Andrew Roberts, January 2009

The Long-Term Effect of the Divorce Revolution: Health, Wealth, and Labor Supply

Kristin Mammen, December 2008

The Response of Household Saving to the Large Shock of German Reunification Nicola Fuchs-Schündeln, November 2008

A Parsimonious Choquet Model of Subjective Life Expectancy

Alexander Ludwig and Alexander Zimper, November 2008

Risky Pensions and Household Saving Over the Life Cycle

David A. Love and Paul A. Smith, November 2008

Identifying Local Differences in Retirement Patterns

Leora Friedberg, Michael Owyang, and Anthony Webb, November 2008

What Effect Do Time Constraints Have on the Age of Retirement?

Leora Friedberg, Wei Sun, Anthony Webb, November 2008

Dual-Eligible Medicaid Spending: Are We on the Flat of the Curve?

Melissa A. Boyle, Joanna N. Lahey, and Margaret E. Czervionke, November 2008

Public Long-Term Care Insurance and the Housing and Living Arrangements of the Elderly: Evidence from Medicare Home Health Benefits

Gary V. Engelhardt and Nadia Greenhalgh-Stanley, November 2008

The Impact of Changing Earnings Volatility on Retirement Wealth Austin Nichols and Melissa M. Favreault, November 2008

All working papers are available on the Center for Retirement Research website (http://www.bc.edu/crr) and can be requested by e-mail (crr@bc.edu) or phone (617-552-1762). 